\title{
Enforced Marriages in Spain: Brief Reference to Regional Regulations and Action Protocols Adopted in the Community of Catalunya
}

\author{
Encarnacion Abad Arenas \\ Department of Civil Law, National University of Distance Education, Madrid, Spain
}

\section{Email address:}

eabad@der.uned.es

\section{To cite this article:}

Encarnacion Abad Arenas. Enforced Marriages in Spain: Brief Reference to Regional Regulations and Action Protocols Adopted in the Community of Catalunya. International Journal of Law and Society. Special Issue: Enforced Marriages in Spain: Brief Reference to Regional Regulations and Action Protocols Adopted in the Community of Catalunya. Vol. 2, No. 3, 2019, pp. 47-53. doi: $10.11648 /$ j.ijls.20190203.14

Received: June 25, 2019; Accepted: August 6, 2019; Published: September 2, 2019

\begin{abstract}
In this text, it is analyzed how, at present, the absence of studies in relation to forced marriages and their undoubted configuration as a concrete manifestation of violence against women and girls, as well as the limited existence of programs developed In this regard, by public entities or administrations, this phenomenon has been perceived in Spain as an isolated case, which only occurs sporadically in some Autonomous Communities and, at the same time, in very restricted ethnic groups. Thus, the approval of Law 5/2008, of April 24, on the right of women to eradicate sexist violence in Catalunya, is justified by the fact that women's rights are human rights, deriving from international, European and national regulations that have developed a set of rights and, both criminal and administrative measures, with the aim of eradicating violence against women, providing within its articles the reference to forced marriages as a macho violence in the social or community sphere. Also, reference is made both to the Catalan Police Protocol on Procedure for the Prevention and Police Care of Forced Marriage (2009), created with the purpose of addressing forced marriages to protect victims - girls / women - from prevention and, when this practice It would have been carried out, such as the Security Program against Violence Machista (2007), which was established in Catalunya, through a working group, its purpose was focused on the study of forced marriages formalized by some of the immigrant people residing in Catalunya, with the understanding that these types of marital links constitute a serious violation of the fundamental rights of their victims, which as a general rule are young women. Finally, it is necessary that in 2014 a Protocol for the approach of forced marriages -which is limited only to the territory of Girona- has been approved, its main objective is to establish a network of health, social services, education and police forces, as well as the adoption of measures to prevent and act in cases of forced marriage.
\end{abstract}

Keywords: Forced Marriage, Minors, Action Protocols, Prevention, Police Attention, Macho Violence

\section{Introduction}

In the first place, it is necessary to specify that forced marriages are supported by traditions or customs offered to the minor as compensation, with the purpose of tackling conflicts or paying outstanding debts, fulfilling obligations or promises of the past, family honor, protecting the cultural or religious ideals (...). Although, it is undeniable that this practice affects the child negatively in their health, education and economic autonomy and even increases the risk of sexually transmitted infections.
Having said that, it should be pointed out that, in Spanish law, although the existence of a wide range of regulations in relation to the regulation of gender violence is observed, the fact is that there is practically no reference to forced marriages, with the exception of its allusion in some regional legislations.

However, it should be borne in mind that, in December 2014, the Ministry of Health, Social Services and Equality and the Children's Observatory developed the Basic Intervention Protocol against child abuse in the family environment [1]. Protocol that would be updated to the 
intervention in cases of minors victims of gender violence.

Keep in mind that with this Protocol -consensus reached at the Plenary of the Children's Observatory on July 9, 2014the Basic Protocol of intervention against child maltreatment of 2007 - carried out by the Children's Observatory, was updated. It was a great progress at that time.

Hence, this document is limited to abuse in the family, provided that other forms of child abuse are treated specifically.

In short, this new instrument limits abuse in the family, foreseeing that other forms of child abuse are treated specifically. In such a way that the family dimension is included in the title of the new document, it incorporates forms of violence against girls, as would be the case, for example, of forced marriages.

In addition, this protocol has been the result of a shared effort, whose main objective is to improve the early detection of child maltreatment in the family, optimizing for this, interinstitutional coordination that allows a quick and effective response to all these possible situations.

In short, two have been the purposes of the aforementioned Protocol: On the one hand, improve the care of minors who are victims of family abuse, thereby avoiding the victimization that could suffer in the intervention process. On the other hand, its updating adapts its content to the scenarios of those that coexist in environments where gender violence originates and some of the forms of violence against girls -as would be the case, among others, of forced marriages- that tend to provoke in the family environment, thus involving the different administrations, institutions, agencies and entities that work with children.

It is also based on the premise that the regulatory framework of reference for this Protocol is found in Resolution 64/145, approved by the General Assembly on December 18, 2009 [on the basis of the report of the Third Committee (A / 64/435 and Corr.1)]. The girl.

Resolution that recognizes both that premature procreation is an impediment to improving the socio-educational situation of minors, and that child marriage and forced marriage -in general terms- seriously endanger their education, thus originating repercussions negative long-term effects on their quality of life and employment.

In addition, and supported by the Declaration of Rio de Janeiro, adopted in 2008, on the one hand, it encourages States to adopt measures that are appropriate to address the root causes of child marriage and forced marriage, as well as as to the realization of educational activities, with the aim of raising awareness about the negative aspects of these practices, on the other, it encourages them to pay special attention to those programs that are destined to the education of women and men and, more especially, those who have children, in relation to the importance that physical and mental health assumes as well, as well as the well-being of the girl, including in this, the elimination of discrimination against the child in marriage in childhood and the forced marriage and, finally, urges all States to enact and enforce laws that protect girls against all forms of violence and exploit tion, including forced marriage.

It also requests "the Secretary-General to submit a report on the implementation of the present resolution, emphasizing, inter alia, the elimination of child marriage and forced marriage, based on the information provided by the Member States, organizations and bodies of the United Nations system and non-governmental organizations, in order to assess the impact of the present resolution on the wellbeing of the girl child" [2].

Protocol that to be viable and can be established in each Autonomous Community, requires to be signed and assumed by the institutions that are involved in each area, by the competent entity in matters of child protection of each Autonomous Community, in addition, to require of an implication by the civil society -ONG's or Associations framed in this field-.

Thus, these organizations must commit themselves to: "Establish in [...] cases of forced marriages, the corresponding coordination between the Child Protection Services and the competent bodies in charge of situations of violence against women in the Communities. Autonomous" [3].

In short, this document, although its aim is to serve as a framework for joint and comprehensive action, the truth is that its development will depend on each Autonomous Community.

\section{Autonomic Regulations}

With regard to the regional legislation, it should be noted that in Spain some Autonomous Communities, with the aim of eradicating and preventing gender-based violence, have enacted laws that include within their regulations the concept of forced marriage, at the same establish prevention plans.

In this sense, article 40 dedicated to the «etection and care in the matter of female genital mutilation and forced marriage> of the Foral Law 14/2015, of 10 April, to act against violence against women, foresees that: "The Administration of the Autonomous Community of Navarre will establish action protocols that will allow attention and detection in cases of female genital mutilation and forced marriage, for which the specific training necessary for the professionals involved will be sought" [4].

Also, the second paragraph of article 40 aimed at the 〈Forms and manifestations of sexist violence〉 of Law 7/2007, of April 4, for Equality between Women and Men, and Protection against Gender Violence in the Region of Murcia, modified by Law 11/2016, of June 15, which modifies Law 7/2007, of April 4, for Equality between Women and Men, and Protection against Gender Violence in the Region of Murcia, states that: "For the purposes of this law are considered manifestations of violence against women, among others [...]: g) Marriage at an early age, arranged or forced marriage: a marriage in which there has been no free and full consent for its celebration, either because it has been the result of an agreement between third parties, unrelated to the will of the women, either because it is held under conditions of intimidation or violence or because the legally envisaged age has not been reached. said consent" [5]. 
Likewise, in the fourth section of article 5 dedicated to the 〈Areas of male violence) of Law 5/2008, of 24 April, on the right of women to eradicate sexist violence, in the Autonomous Community of Catalunya, that "violence in the social or community sphere includes, among others, the following manifestations: e) forced marriages" [6].

Also, in the first section of article 14, which is aimed at the (Protection against sexual exploitation, trafficking in minors and other forms of violence> of Law 26/2018, of 21 December, of the Generalitat, on rights and guarantees of Childhood and Adolescence, of the Generalitat Valenciana, states that: "The Generalitat shall adopt the administrative measures and social programs necessary to prevent and protect children and adolescents from any form of exploitation of their sexuality, prostitution and child pornography, forms of violence such as genital mutilation and forced marriage and to ensure that they are not subject to any type of trafficking, sale or theft. Particular attention will be paid to the protection of those who are particularly vulnerable to these practices" [7].

And adds in its third paragraph that: "The Generalitat will establish protocols for identification, action and attention against genital mutilation, forced marriage, trafficking in minors for the purpose of sexual exploitation or sale, prostitution or use in pornography" [8].

In this sense, article 4 dedicated to the «Manifestations of gender violence> of Law 4/2018, of 8 October, for a Society Free of Gender Violence in Castilla-La Mancha, to specify that: "For the purposes of this law, the following manifestations of violence towards women are included within the scope of gender-based violence: [...] f) Marriage or pairing at an agreed or forced early age: a marriage or marriage in the that there has been no free and full consent on the part of the woman, either because it has been the result of an agreement between third parties, alien to the woman's will, either because it is celebrated under conditions of intimidation or violence or because it has not been reached the legally envisaged age to grant such consent" [9].

Also, the fourth section of article 3 dedicated to the 〈Concept, typology and manifestations of gender violence〉 of Law 7/2018, of July 30, which modifies Law 13/2007, of November 26, preventive measures and comprehensive protection against gender violence, Andalusia, provides that: "For the purposes of the provisions of this Law, will be considered acts of gender violence, among others, the following manifestations: j) Marriage precocious or forced, understood as a marriage in which there was no free and full consent of the woman to celebrate it, either because it was the result of an agreement between third parties, alien to the will of the woman, or because it was held under conditions of intimidation or violence or because the legally envisaged age to grant such consent or lack of capacity to provide it has not been reached, even if at the time of the celebration there was no yielded to his judicial incapacitation" [10].

On the other hand, in other regional legislations reference has been made to this type of marriage in its Preamble. In this sense, Law 11/2007, of 27 July, Galician for the prevention and comprehensive treatment of gender-based violence, of the Autonomous Community of Galicia, refers to forced marriages, referring to the provisions of the Commission of Human Rights of the UN, in the following terms: "In 2002 the UN Commission on Human Rights, in its Resolution 2002/52, on the elimination of violence against women, while clearly condemning all acts of violence perpetrated against women and girls, includes in its definition of gender violence not only the various manifestations of it that were already included in this category, but also new ones such as: crimes of passion, early and forced marriage, the infanticide of girls, acid attacks and violence related to commercial sexual exploitation and economic exploitation" [11].

Also, it has been the case of Law 13/2010, of December 9, against gender violence in Castilla y León, when stating that: "The UN Human Rights Commission in Resolution 2002/52 includes new acts of gender violence such as: crimes of passion, early and forced marriage, the infanticide of girls and attacks of acid and violence related to commercial sexual exploitation and economic exploitation" [12].

In addition, and in accordance with the Istanbul Convention, Law 1/2017, of 17 March, amending Law 16/2003, of 8 April, on the Prevention and Integral Protection of Women against Gender-based Violence, of the Canary Islands, has stated that: "The Istanbul Convention recognizes that violence against women is a manifestation of the historical imbalance between women and men that has led to the domination and discrimination of women by men, depriving them of his full emancipation" [13].

In addition, this Law specifies that "it recognizes that this type of violence is one of the crucial social mechanisms by which women are kept in a position of subordination with respect to men. Likewise, there is a special and worrying recognition, regarding women and girls exposed to serious forms of violence such as sexual harassment, rape, forced marriage (...)" [14].

On the other hand, in March 2007, the General Committee of the Autonomous Communities of the Senate, adopted the proposal of approval in this Commission of the motion before the Plenary session by means of which the Senate was favorable to reach a State Pact against Violence of Gender, thereby protecting both women and their children.

More recently, in 2017 at the proposal of the Socio-Legal Commission of the Immigration Forum, the Plenary of the Forum of Immigration in Aragon has agreed to approve by "unanimity" the Recommendation of the mentioned Forum in relation to forced marriages.

Keep in mind the reader that this commission worked during the year 2017 and the first semester of 2018 on those issues that presented greater vulnerability. Issues in which some migrant women find themselves, with the aim of establishing what these situations are, their consequences and the possible tools for their prevention.

Thus, on June 5, 2018, the Socio-Legal Committee met, addressing the issue of forced marriages, highlighting the seriousness of this practice and noting that this practice is carried out with girls and boys and young people residing in the 
Autonomous Community of Aragon require the need to carry out a protocol to prevent forced marriages and support victims.

From the above, the Plenary of the Forum agreed to elevate this Recommendation to the General Directorate of Equality and Families and to the Aragonese Institute for Women, so that it can be carried out.

\section{Brief Reference to the Protocols of Intervention Adopted in the Catalan Community}

As announced in previous lines, there are practically no studies on forced marriages, configured as a concrete manifestation of violence against women, in addition to the few programs that have been developed in this regard by the entities or public administrations.

However, it should be noted that this phenomenon in Spain is perceived as an isolated case, which only takes place sporadically in some very restricted communities and ethnic groups.

As already announced, the Parliament of Catalunya promulgated in 2008 Law 5/2008, of April 24, on the right of women to eradicate sexist violence. Law that finds its justification in the fact that women's rights are human rights, deriving from the international, European and national regulations that have developed a set of rights and criminal and administrative measures to achieve the eradication of violence against women.

In addition, in section four of Article 5 includes a broad concept of sexist violence, as well as all types of violence suffered by women in any field, including in its letter e) the reference to forced marriages as a sexist violence in the social or community scope.

In this sense, some authors foresee that "the law already recognizes forced marriage as a practical manifestation of sexist violence in the social and community sphere, establishing a series of guarantees and rights for victims of forced marriages" [15].

However, the above in Catalunya only has police statistics of the Mossos d'Esquadra, because the regional law of sexist violence recognizes forced marriages as a form of gender violence in the community and, consequently, forces these police forces to register specifically the few cases that reach their hands [16].

In this sense, migratory flows and globalization have led to the transfer of certain practices or customs to places where they were not traditionally carried out, in such a way that they have allowed people from these origins to develop their life project in countries of the same context. European, where this practice was unknown.

Thus, in the case of Catalunya, the Generalitat Police -Mossos de Esquadra- intervened in 2009: in 13 cases of forced / forced marriages (in 7 the victim was minor); in 2010: 15 cases (in 8 the victim was minor); in 2011: 21 cases (in 13 the victim was minor); in 2012: 16 cases (in 12 the victim was minor); in 2013: 26 cases (in 15 the victim was minor); in 2014: 10 cases (in 6 the victim was minor); in 2015: 16 cases (in 8 the victim was minor); in 2016: 14 cases (in 10 the victim was minor); in 2017: 10 cases (in 3 the victim was minor); in 2018: 12 cases (in 4 the victim was minor); in 2019 (First semester): 6 cases (in 4 the victim was minor) [17].

Hence, the enormous difficulties that have arisen in detecting this type of marriage have left vulnerable young or young people who are immersed in a family at risk. So avoiding a forced marriage, organized as a general rule by the parents and even by the extended family, has an important cost in the family relational field.

In addition, it is based on the fact that this family context can react negatively against what it considers a "westernized behavior" of the minor or of the woman who debates the code of traditional customs of the culture of origin, in the understanding of that the family honor is damaged and, therefore, the prestige of the family [18].

However, keep in mind that the truth is that this illegal type of marriage practices are still detected, although they are difficult to quantify in exact terms. Difficulty due mainly to two reasons: on the one hand, because girls / women live or are controlled by their parents, it is impossible for them to formalize the relevant complaint. Denounces that, should it come to intervene, it ends up being withdrawn for fear of reprisals that could be taken by their relatives, those of the future husband or husband if the marriage has taken place or, because the victims accept the right not to testify under of the family relationship that unites them with these. On the other hand, due to the lack of knowledge of rights and resources placed at their disposal [19].

In addition, the fundamental reason to keep in mind in the cases of kidnapping or illegal detention carried out by the parents of the victims, in order to prevent them from relating to people of culture or religion other than their own, is machismo. Machismo rooted in a custom with patriarchal roots, which implies that the woman has no voice or vote, forced to occupy a role of submission and inferiority in front of the male, and, consequently, being dependent on the husband total, complete and forced [20].

By way of example, in the Judgment of the Supreme Court, Room 2, of January 8, 2010 (LAW 5323/2010) the case of a minor of 14 years old, taken to her country of origin to marry was resolved. forced with an adult man. Minor tan later- she was transferred back to Spain by her mother, where she was physically and psychologically attacked by her parents and by her husband -aggressions caused by the refusal of the minor to have sexual relations with him-. From the foregoing and in light of the evidence provided, the High Court issued the following conviction: "To the parent as a necessary cooperator of a crime of sexual assault and as the author responsible for a crime of family abuse, serious injury to family members; of coercion and threats; to the parent as the perpetrator responsible for a crime of family abuse and, threats and, finally, to the husband as the person responsible for a crime of sexual aggression" [21].

On the other hand, in the Judgment of the Provincial Court of Barcelona, Section 21, of May 26, 2009 (LAW 
$322684 / 2009$ ), a case of illegal detention of a young woman who was forced to abandon her work place -staying at homeby one of her parents and, by her brother, so that she did not relate to her boyfriend of Spanish origin. Trial for illegal detention in which the complainant took advantage of her right not to testify [art. $416 \mathrm{LECr}$ ] by virtue of the family relationship that united him with those denounced. In view of the facts, the Court proceeded to the acquittal of those accused of the crime of which they were accused.

Also, in June 2009, in order to address forced marriages to protect victims -girls / women- from prevention or when this practice had been carried out, the Government of Catalunya created the Catalan Police Protocol of «Prevention Procedure and police attention to forced marriage>, in order to make visible a practice that is difficult to detect, an incidence that takes place between certain communities of foreign origin residing in said Community.

This protocol that includes the definition of these marriages, their geographic location, their motivations and, compiles the legal framework and the procedure to be followed, has as pretense to avoid the victimization of women and minors [22].

In addition, it should be pointed out that this Protocol is based on the idea that forced marriages are a practice that continues to be valid in the countries and communities of origin of some immigrants who develop their life project in Catalunya. In addition, it takes as reference the Protocol of the Association of Chiefs of the British Police, the British Ministry of Foreign Affairs and the British Ministry of the Interior, national and local bodies of education, health and social services and ONG's.

In short, this procedure aims to prevent and punish these unions, typical of underdeveloped societies, where puberty and maturity have the same meaning. Societies in which women have the consideration of object, property or simple merchandise and in which the value of the girl lies in its purity or virginity [23].

However, and prior to the above, within the framework of the 〈Program of Security against Sexual Violence〉 created in 2007 - by the Department of the Interior - a working group was established in Catalunya for the analysis and study of forced marriages, made by some of the immigrants residing in Catalunya, justifying this, in that this type of marriage is a serious violation of fundamental rights and its victims are young women who are forced to marry in their countries of origin.

Program in which forced marriages are studied, because they are considered as a practice that continues in force, both in the countries and communities of origin of immigrants they live in Catalunya [24].

It is also worth mentioning the actions carried out by the Prosecutor's Office for the Protection of Minors of Catalunya in 2002, which, when considered as the first preventive measures adopted in response to said practices, were put into operation after knowledge of various cases of sale of young girls for celebration of marriages agreed by their parents.

These measures are specified -following the United
Kingdom- in the withdrawal of the passport to minors who were in such cases, in order to prevent their leaving the country and, therefore, the ensuing conclusion of forced marriage in their country of origin.

In addition, the Office of the Prosecutor prepared an internal report describing the physical and mental abuse suffered by the minors who opposed these non-consensual marriages. Report in which the assistance of her parents to human rights courses was proposed as a reeducation measure - a measure adopted in the Nordic countries.

It should also be pointed out that, in 2014, a Protocol was approved to address forced marriages in Girona, whose aim is to establish a network of health, social services, educational and police forces, and adoption. measures to prevent and act in cases of forced marriage, although limited to the territory of Girona [25].

\section{Conclusions}

Nowadays, in some countries of Muslim religion, although marrying a minor is a crime, the fact is that the practice of marriage with minors is done on a regular basis, because these communities are governed by their own "religious traditions or customs ancestral".

So, this type of marriage when becoming evident in Spain -as well as in other European countries-, due to the recent detection of some cases linked to migratory phenomena and population movements among which this system still survives, has caused that In some Autonomous Communities, different procedures and initiatives have been adopted, with the purpose of proceeding with their eradication.

In this sense, in Catalunyaa, with the enactment of Law $5 / 2008$, of April 24, in addition to finding its justification that women's rights are human rights, it includes a broad concept of sexist violence, and all types of violence suffered by women in any field, including forced marriages within them, configured as a sexist violence in the social or community sphere.

Definitely, at present, Catalan legislation configures forced marriage as a manifestation of sexist violence, protecting victims through a wide range of rights and, of guarantees.

\section{References}

[1] Observatory of Childhood. Ministry of Health, Social Services and Equality, (2014). "Basic Protocol of Intervention against Child Mistreatment in the Family. Updated to the intervention in the cases of minors victims of gender violence". Available at: https://www.bienestaryproteccioninfantil.es/imagenes/tablaCo ntenidos03SubSec/MaltratoInfantil_accesible.pdf (Last visited on May 24, 2019).

[2] United Nations - General Assembly, (2010): "Resolution adopted by the General Assembly on December 18, 2009 [on the basis of the report of the Third Committee (A / 64/435 and Corr.1)]. [A / RES / 64/145] The girl". Available at: http://www.un.org/en/ga/search/view_doc.asp?symbol=A/RES /64/145\&Lang=S (Last visited on May 28, 2019). 
[3] Navarra Foral Law 14/2015, APRIL 10, to act agains violence towomen (Text published in BON No. 71 of April 15, 2015). Available

http://www.lexnavarra.navarra.es/detalle.asp?r=35670 (Last visited on July 27, 2019).

[4] Law 11/2016, of June 15, which modifies Law 7/2007, of April 4, for Equality between Women and Men, and Protection against Gender Violence in the Region of Murcia, (Text published in BORM No. 139 of June 17, 2016). Available at: https://www.boe.es/diario_boe/txt.php?id=BOEA-2016-6648 (Last visited on July 27, 2019).

[5] Law 5/2008, of April 24, on the right of women to eradicate sexist violence, of the Autonomous Community of Catalunya, (Text published in DOGC No. 5123 of May 02, 2008). Available at: $\mathrm{http}: / /$ noticias.juridicas.com/base datos/CCAA/ca-152008.html (Last visited on July 27, 2019).

[6] Law 26/2018, of December 21, of the Generalitat, of rights and guarantees of Children and adolescents, of the Generalitat Valenciana, (Text published in DOGV No. 8450 of December 24, 2018). Available at:

https://www.dogv.gva.es/portal/ficha disposicion pc.jsp?sig= $011597 / 2018 \& \mathrm{~L}=1$ (Last visited on July 27, 2019).

[7] Law 26/2018, of December 21, of the Generalitat, of rights and guarantees of Children and adolescents, of the Generalitat Valenciana, (Text published in DOGV No. 8450 of December 24, 2018). Available at:

https://www.dogv.gva.es/portal/ficha_disposicion_pc.jsp?sig= $011597 / 2018 \& \mathrm{~L}=1$ (Last visited on July 27, 2019).

[8] Law 4/2018, of October 8, for a Society Free of Gender Violence in Castilla-La Mancha, (Text published in BOE No. 301, of December 14, 2018). Available at: https://www.boe.es/diario boe/txt.php?id=BOE-A-201817065 (Last visited on July 27, 2019).

[9] Law 7/2018, of July 30, which modifies Law 13/2007, of November 26, on prevention measures and comprehensive protection against gender violence, in Andalusia, (Text published in BOE No. 207, of August 27, 2018). Available at: https://www.boe.es/diario_boe/txt.php?id=BOE-A-201811883 (Last visited on July 27, 2019).

[10] Law 11/2007, of July 27, Galician for the prevention and comprehensive treatment of gender violence, of the Autonomous Community of Galicia, (Text published in BOE No. 226, of September 20, 2007). Available at: https://www.boe.es/diario_boe/txt.php?id=BOE-A-200716611 (Last visited on July 27, 2019).

[11] Law 13/2010, of December 9, against gender violence in Castilla y León, (Text published in BOCL No. 243 of December 20, 2010). Available at: $\mathrm{http}: / /$ noticias.juridicas.com/base datos/CCAA/cl-1132010.tp.html (Last visited on July 27, 2019).

[12] Law 1/2017, of March 17, amending Law 16/2003, of April 8, on Prevention and Integral Protection of Women against Gender Violence, of the Canary Islands, (Text published in BOE No. 160, of July 6, 2017). Available at: https://www.boe.es/diario_boe/txt.php?id=BOE-A-2017-7819 (Last visited on July 27, 2019).

[13] Law 1/2017, of March 17, amending Law 16/2003, of April 8, on Prevention and Integral Protection of Women against Gender Violence, of the Canary Islands, (Text published in BOE No. 160, of July 6, 2017). Available at: https://www.boe.es/diario boe/txt.php?id=BOE-A-2017-7819 (Last visited on July 27, 2019).

[14] Observatory of Childhood. Ministry of Health, Social Services and Equality, (2014). "Basic Protocol of Intervention against Child Mistreatment in the Family. Updated to the intervention in the cases of minors victims of gender violence". Available at: https://www.bienestaryproteccioninfantil.es/imagenes/tablaCo ntenidos03SubSec/MaltratoInfantil accesible.pdf (Last visited on July 27, 2019).

[15] Heim, D, Fernández Bessa, C and Bodelón González, E. (2013): "Progetto IRIS - Interventi contro la violenza di genere verso le donne: ricerca e sperimentazione di sportelli specializzati". [JLS / 2008 / DAP3 / AG / 1246 30CE03119160027]. Research report Catalunya. Autonomous University of Barcelona. Available at: www.leonde.org/iris1/report/catalunya.pdf (Last visited on May 28, 2019).

[16] Igareda González, N. (2015): "Forced marriages: another opportunity for symbolic criminal law", Journal for the analysis of law, pp. 1-18, 7.

[17] Departament d'Interior, Generalitat de Catalunya, (2019): Dades on massaclist violence. Gifts (years 2009 to 2019). Available http://interior.gencat.cat/ca/arees_dactuacio/seguretat/violenci a-masclista--domestica/estadistica-sobre-violencia-masclista-domestica/dades-sobre-violencia-masclista-dones/ (Last visited on May 30, 2019).

[18] Generalitat de Catalunya, (2009): "Seguretat Program against Masculist Violence. Procedure of prevention and police attention of forced marriages". Departament d'Interior, Institutional Relations and Participation. Available at: http://bbpp.observatorioviolencia.org/wpcontent/uploads/2018/05/DOC1261477148_Presentacio_Proc edimiento-MF 20090603 espanol.pdf (Last visited on May 30, 2019).

[19] Abad Arenas, E. (2017): "The protection of the rights of adolescence: forced marriages and the change of the nubile age", in The Law. Family Law: Legal Magazine on Family and Minors, no. 13, (Issue dedicated to: The (in) capacity of children and adolescents in Spanish law), pp. 151-159, 154.

[20] Abad Arenas, E. (2015): "Marital freedom and project for the typification of forced marriages". In: The future of social policies from birth to old age: Women as protagonists, Crespo Garrrido and Moretón Sanz (Dirs.), Editorial Tirant lo Blanch, Madrid, pp. 121-140, 133.

[21] Supreme Court Judgment, Room 2, of January 8, 2010 (LAW 5323/2010). (Last visited on July 27, 2019).

[22] Abad Arenas, E. (2014): "Marital Freedom and Forced Marriages," in Diario La Ley, no. 9907, pp. 1-9, 7.

[23] Abad Arenas, E. (2012): "Arranged marriages, forced marriages, early marriages: Nullity due to lack of consent". In: Civil Law Studies in Homage to Mr. Joaquín Rams Albesa, (Coord.), Cuena Casas, Anguita Villanueva and Ortega Doménech, Dikynson, Madrid, 1st ed., pp. 1079-1096, 1090.

[24] Rojo Álvarez-Manzaneda, C. (2018): "Forced marriage as a form of gender violence. Approach of the main religious confessions". In: The Istanbul Convention as a framework of anti-sub-discriminatory law, Gil Ruiz (Ed.), Dykinson, Madrid, pp. 135-165, 143. 
[25] Generalitat de Catalunya - Gerona, (2014): "Protocol for dealing with forced marriages". [1st Update November 2016]. Available at: http://dones.gencat.cat/web/.content/03 ambits/docs/vm proto col_matrimonisforcats_girona_ES.pdf (Last visited on June 6, 2019). 